\begin{tabular}{l|l}
\hline ISTEMA \\
ELERONNICO \\
DE REVISTAS \\
SER I UFPR \\
unw.ser.ufpr.br \\
\end{tabular}

\title{
Editorial
}

\section{5 anos do Programa de Pós-Graduação em Meio Ambiente e Desenvolvimento}

\section{5 years of the Graduate Program on Environment and Development}

Este volume especial da revista Desenvolvimento e Meio Ambiente tem um duplo objetivo: comemorar os 25 anos do Programa de Pósgraduação em Meio Ambiente e Desenvolvimento (PPGMADE) que se cumprem neste ano e homenagear uma de suas principais incentivadoras e fundadora, a professora Magda Zanoni, falecida em maio de 2015.

Esses dois propósitos foram norteadores para a realização de um Colóquio comemorativo dos 22 anos do programa em 2016, em que professores, alunos e pesquisadores de várias instituições federais e internacionais discutiram desde as bases fundadoras do programa como sua feição atual, incluindo aí a missão constitutiva do PPGMADE: produzir e ensinar um conhecimento das relações natureza-sociedade através da interdisciplinaridade, questionando as visões estanques da questão ambiental.
Assim, apresentamos o texto de Claude Raynaut - ele também um dos fundadores do programa - intitulado "Paradoxos e ambiguidades na ideia de interdisciplinaridade", na sua língua original (francês) e com a tradução para português. Na sequência, publicamos dois textos sobre o MADE - o primeiro, de Dimas Floriani, intitulado "História da construção da pós-graduação interdisciplinar em Meio Ambiente e Desenvolvimento (PPGMADE-UFPR): aspectos epistemológicos, metodológicos e institucionais", e o segundo, de Cristina de Araújo Lima e Rafaela Antunes Fortunato, intitulado "Aspectos do perfil dos egressos do PPGMADE em 22 anos e o efeito multiplicador da formação dos doutores". Por fim, o texto de Carlos Alberto Cioce Sampaio e colaboradores, discutindo um tema que abre uma perspectiva de sociedade dentro dos marcos de uma nova percepção ambiental: "Bem viver e ecossocioeconomia - entre subjetividade e o bem comum". 
Para homenagear a Professora Magda Zanoni, reunimos pessoas que conviveram com ela em suas profícuas atividades e recolhemos depoimentos que demonstram sua grande contribuição para a formação interdisciplinar no Brasil e para várias iniciativas que propunham um desenvolvimento socialmente mais equitável e preservador da natureza. Também republicamos aqui algumas das muitas homenagens póstumas prestadas a ela por pessoas ligadas a universidades, a ONGs e a órgãos de governo em que atuou, tanto no Brasil como na França. Por fim, publicamos uma entrevista que Magda Zanoni concedeu a Cleyton Gerhardt em 03/06/2006, inédita até agora.

Complementamos esta edição comemorativa dos 25 anos do PPGMADE com a republicação de textos selecionados dos fundadores do programa que são peças importantes do nosso patrimônio intelectual e que, no seu momento, foram publicados apenas de forma impressa nos cadernos que precederam a esta revista, faz muito tempo esgotados. Procurou-se, no caso, publicar as versões em português e francês, se assim estavam no original. Esperamos, pois, que este volume apresente os desdobramentos do PPGMADE para aqueles que se interessam pelo programa ou iniciam sua formação nele, assim como para a comunidade científica nacional e internacional em geral. Esperamos, igualmente, que permita conhecer a atuação e personalidade de Magda Zanoni para aqueles que não tiveram o privilégio de trabalhar ou conviver com ela.

Os Editores 